\title{
MANIFESTAÇÕES VAMPIRESCAS SOB INSÓLITOS OLHARES ANGOLANOS: NARRATIVAS FANTÁSTICAS DE ANA PAULA TAVARES E JOSÉ EDUARDO AGUALUSA
}

Flavio García (UERJ)

Resumo: Na "Nota introdutória" a Contos de vampiros, Pedro SenaLino, coordenador do volume, observa que "Os contos de vampiros são um tipo de narrativa que se integra no gênero fantástico" e destaca que, "Segundo Tzvetan Todorov, este gênero caracteriza-se por 'uma hesitação: o leitor tem de integrar o que se passa na realidade ou na ficção'. Ou seja: o leitor, enquanto lê, tem de tomar uma decisão, e nesse espaço de dúvida acontece o fantástico, essa hesitação". Dentre os autores que compõem a coletânea, encontram-se os angolanos Ana Paula Tavares e José Eduardo Agualusa, que conseguiram instaurar, em seus contos, um clima próprio ao fantástico, onde reina a hesitação, incerteza ou ambiguidade. A narrativa de Ana Paula é toda ela ambientada em África e se nutre de crenças telúricas, permeando o animismo. A narrativa de José Eduardo tem início no Brasil, mais precisamente no Rio de Janeiro, e migra para Luanda, em Angola, onde se dão as ações nucleares do fantástico, terminando com um diálogo que tensiona passado-presentefuturo, entre África e Brasil, consagrado pela dúvida final, experienciada pelo destinatário intratextual e transmitida ao leitor. O que se observa nessas duas narrativas é, essencialmente, como esses dois escritores africanos, que carregam consigo, por origem de nascimento, a convicção de um quotidiano realismo insólito, mas que vêm sendo ambientados em Portugal ou Brasil, encontram-se encharcados de experiências globalizadas, permitindo-se escrever contos de vampiros na esteira da ficção fantástica, o que, no geral, contrapõe-nos a mais tradicional crítica literária - e cultural, por extensão - africana.

Palavras-chave: Fantástico; Insólito; Personagem; Vampiro; Literatura Angolana.

Abstract: In "Nota Introdutória" to Contos de Vampiros, Pedro Sena-Lino, volume coordinator, notes that "Vampire tales are a type of narrative that integrates into the fantastic genre" and points out that, "According 
to Tzvetan Todorov, this genre characterizes for 'a hesitation: the reader has to integrate what is happening in reality or in fiction'. That is: the reader, while reading, has to make a decision, and in that space of doubt happens the fantastic, this hesitation". Among the authors that make up the collection are the angolans Ana Paula Tavares and José Eduardo Agualusa, who managed to establish in their stories a climate unique to the fantastic, where hesitation, uncertainty or ambiguity reigns. The narrative of Ana Paula is all set in Africa and is nurtured by telluric beliefs, permeating animism. The narrative of José Eduardo begins in Brazil, more precisely in Rio de Janeiro, and migrates to Luanda, in Angola, where the nuclear actions of the fantastic are given, ending with a dialogue that stresses past-present-future, between Africa and Brazil, consecrated by the final doubt, experienced by the intratextual recipient and transmitted to the reader. What is observed in these two narratives is essentially how these two African writers, who carry with them, by origin of birth, the conviction of an unusual everyday reality, but which have been set in Portugal or Brazil, are soaked with experiences globalized, allowing to write tales of vampires in the wake of fantastic fiction, which, in general, contrasts with the more traditional literary and cultural, by extension - African criticism.

Keywords: Fantastic; Uncanny; Character; Vampire; Angolan Literature.

\section{Conforme observa Sena-Lino, em sua "Nota} introdutória" a Contos de vampiros, por ele organizado, "Os contos de vampiros são um tipo de narrativa que se integra no gênero fantástico" (2009, p.9). Foi essa observação do coordenador do volume, com três narrativas de escritores angolanos, que instigou esta reflexão, pois é comuníssimo ouvir, da ampla maioria dos estudiosos das literaturas africanas, em especial daqueles que estudam as literaturas dos PALOP, e, notadamente, a de Angola, que "não há literatura fantástica em África, porque a realidade de África é 
por si só fantástica" - alguém poderá dizer que não identifico as fontes dessa assertiva que reproduzo, mas não o faço com a consciência de não querer provocar celeumas gratuitas, e vista a carapuça quem ache que ela lhe sirva bem à cabeça.

Assim, deparar-me, nessa coletânea, assumidamente compilada com foco na literatura fantástica, como bem anuncia, desde o pórtico, seu coordenador, contendo narrativas escritas por autores angolanos, dentre as quais, duas se amoldam, exemplarmente, ao fantástico, despertou minha atenção. Essa foi a razão de eu me remeter, no título deste ensaio, aos "insólitos olhares angolanos", tendo em vista os sujeitos produtores - nativos de Angola - e considerando os mundos possíveis ficcionais que armam espaço, tempo, personagens, ações, objetos e efabulação incongruentes a partir das expectativas da lógica racional e aristotélica, prenunciada por Sena-Lino.

II. Filipe Furtado, quando tratou de tipos e funções de personagens na literatura fantástica, ao problematizar a caracterização do Monstro - que divide a cena fantástica com a Vítima e o Exterminador -, sobrelevou a figura do vampiro, chegando a afirmar que "mais do que qualquer outra entidade ou manifestação metaempírica, o vampiro revela-se, no fantástico vitoriano, uma figura subversiva 
por excelência" (1987, p.508). Para ele, o vampiro, ao lado do lobisomem, é uma das "duas variantes de entidades sobrenaturais que [...] passariam a ter uma presença muito frequente no fantástico" (1987, p.191). Furtado vê essa figura como elemento de coligação entre diferentes mundos e estados. Segundo anota, "o vampiro é [...] uma das figuras fictícias em cujo universo semântico a confluência entre pulsões de vida e pulsões de morte mais tende para uma quase plena simbiose, tornando-o literalmente um 'cadáver adiado que procria"” (1987, p.508), com o que personifica "a intenção [do morto] de retornar ao mundo dos vivos como vampiro" (1987, p.507). Enfim, para Furtado, o vampiro seria uma das mais emblemáticas figuras da ficção fantástica.

A publicação de Sena-Lino contém nove narrativas, sendo seis delas assinadas por escritores portugueses Hélia Correia, João Tordo, Jorge Reis-Sá, Miguel Esteves Cardoso, Rui Zink e Susana Caldeira Cabaço - e três, por angolanos - Ana Paula Tavares, Gonçalo M. Tavares e José Eduardo Agualusa. Dessas três, selecionei apenas as de Ana Paula Tavares e de José Eduardo Agualusa. Como destaca o organizador da coletânea, "Segundo Tzvetan Todorov, este gênero [fantástico] caracteriza-se por 'uma hesitação: o leitor tem de integrar o que se passa na realidade ou na 
ficção'. Ou seja: o leitor, enquanto lê, tem de tomar uma decisão, e nesse espaço de dúvida acontece o fantástico, essa hesitação" (SENA-LINO, 2009, p.9), e aqueles dois escritores conseguiram instaurar, no mundo possível ficcional de seus contos, um clima de hesitação - expressão empregada por Todorov (1992 [1970]) -, incerteza - preferida por Irene Bessière (1973) - ou ambiguidade - eleita por Filipe Furtado (1980), aproximando-os do universo do fantástico literário. O mesmo não se verifica no conto de Gonçalo M. Tavares, que apenas tangencia o gênero - ou modo, ou discurso, ou categoria, ou vertente ficcional etc. - fantástico, sem a ele aderir plenamente.

III. A narrativa de Ana Paula Tavares, "O mistério da Rua da Missão" (2009, p.13-17), é, toda ela, ambientada em África e se nutre das crendices telúricas, permeando o animismo, o que permite apontá-la como espécime do real-animista, conforme algumas parcelas da crítica vêm tendendo a fazer, na esteira de Pepetela, a partir de Luegi:o nascimento de um império (1997 [1990]), quando se deparam com essa vertente da literatura africana, que inscrevo no insólito ficcional.

Semelhantemente ao escritor brasileiro Murilo Rubião (1916 - 1991), expoente da ficção fantástica nacional, Ana Paula inicia por uma epígrafe, não conforme as dele, que 
retoma textos da tradição cristã, mas o faz indo ao âmago da tragédia ática, universo originário da literatura grega, resgatando uma fala do cego Tirésias, proferida contra Creonte. A escritora vai, assim, às matrizes do maravilhoso, que, para a expressiva maioria de estudiosos do fantástico, é um de seus gêneros vizinhos, a partir do qual se estabelecem, teórica e metodologicamente, estratégias de confronto, com limites de interseção e exclusão, que o permitem delimitar distintivamente - de novo, pode-se dizer que não identifico as fontes dessa maioria que menciono, mas qualquer estudioso do fantástico, por mais iniciante que possa ser, já as encontrou em Todorov, Bessière, Furtado ou nos mais contemporâneos estudiosos do assunto que neles beberam.

“Manténs, aqui na Terra, alguém que na verdade pertence aos que estão em baixo" (TAVARES, 2009, p.13), teria dito Tirésias a Creonte. Essa frase, apropriada por Ana Paula para epígrafe, dialoga com a concepção que Furtado apresenta do vampiro na ficção fantástica. Para ele, o vampiro é sempre um ser que deveria, na condição de morto, ter abandonado o mundo dos vivos, mas que, contrariamente, nele permanece vivo-morto ou morto-vivo e, habitando este entre-lugar e levando outros seres humanos ao mesmo estado, ao Ihes cravar os caninos prolongados no pescoço e 
sugar o sangue de que se alimenta. O rito representa, a um só tempo, a morte de um ser humano e o nascimento de um novo vampiro, cuja existência, se não interrompida por ações de foro ritualístico, será infinita.

A crendice telúrica, que desencadeia a narrativa, é enunciada logo em seu primeiro parágrafo, prenunciando os acontecimentos a seguir:

Diziam as mães que quem subia a Rua das Missões devia tomar algumas precauções: baixar o cesto, usar pano bem traçado, não ter um bubu molhado, tirar a criança das costas e ter ao pescoço, pela ordem certa, os três cordões de missangas, vermelho, branco e azul. As mulheres grávidas eram aconselhadas pelas mais velhas a desviar-se dessa rua, especialmente de uma certa travessa. (2009, p.13)

Assim, a narração inicia-se por um verbo dissente "diziam" -, no pretérito imperfeito do indicativo - um dos tempos verbais mais propícios ao discurso fantástico -, instaurando a suspensão (ou suspeição) da ação narrada e gerando a tal hesitação, incerteza ou dúvida de que falam os teóricos que estudam o tema. Fora isso, remete a ação para um passado temporalmente ilimitado, deixando-a em aberto contínuo, o que é outra propriedade comum a muitas narrativas fantásticas. E a terceira pessoa do plural 
em que o verbo se encontra flexionado corresponde a um sujeito - "mães" - cuja indeterminação objetiva amplifica a imprecisão acional - ou, ainda, actancial: sujeito da ação e circunstâncias que a envolvem - e intensifica, desse modo a indefinição.

A narrativa segue repleta de índices discursivos que apontam irrupções do estranho ou sobrenatural, e, atando fios com as tradições locais, ao aludir aos ancestrais ali enterrados, o narrador - em primeira pessoa do plural, em função homodiegética - comenta que "A rua, de vez em quando, parecia mudar de lugar, deixando um olho aberto para as profundezas onde nascia o silêncio e descansavam, pensava a avó Faninha, os antepassados" (2009, p.13). Com esse comentário, igualmente, recupera a epígrafe e não se afasta da concepção que Furtado tem do vampiro - ser do outro mundo, que se mantém presente no mundo dos vivos, ou, em suas próprias palavras, "cadáver adiado que procria".

Nessa rua, que, "de vez em quando, parecia mudar de lugar", o "antigo no 77 [...] era uma espécie de não-lugar porque, em boa verdade, não existia nem do lado par nem lado ímpar da rua" (2009, p.14), e todos ficavam intrigados com isso, buscando entender. "Só a avó Faninha parecia não se incomodar com o facto e, tal como para outras 
coisas, transportava o mistério dentro do coração" (2009, p.14). Anuncia-se, assim, um mistério, um enigma, caso a se resolver. Ainda nesse aspecto, a narrativa de Ana Paula estabelece outro vínculo com o fantástico, aproximando-se da proposição de Bessière ao sugerir que a questão central do modo - termo que a estudiosa prefere, a gênero - são "caso e adivinhação" (2001).

Cenas de um quotidiano nada racionalista e aristotélico pululam em meio à história, reavivando laços entre um mundo referencial de base animista - no qual podemos dizer que essas narrativas, em África, vão buscar seus elementos de armação - e o mundo possível ficcional armado a partir dele - que o dão existência intencional na tessitura narrativa. Em posição intradiegética, o narrador diz:

Não sabemos se [a avó Faninha] morreu e voltou, porque já a conhecemos velha [...], sempre de sorriso aberto, na sua cara de mil rugas e muitos dentes. Alguma coisa devia ter acontecido porque, sempre que se falava de Dona Filomena, avó do nosso vizinho Luvualu, a avó Faninha benzia-se, retirava, do seu quarto, a pá do fumo e acendia alecrim, açúcar e folhas de louro e, enquanto fumigava a casa toda, dizia:

"Ela roubou-me a minha morte. A minha forma de morrer tinha acabado ali. Demorei anos a preparar com detalhe os tempos da minha morte. Tinha que 
ser em segredo, rápida e muito bela. Não havia lugar para a decadência, a despedida, a agonia e todos esses passos antigos que lembravam casas velhas $e$ mulheres de roupas brancas nas mãos, água a ferver, sopa e chá. [...]

"Deixei de beber vinho e perdi o encanto da cerimónia. Copos de vidro a tocar-se com leveza, mãos de carícia alongadas pelas garrafas encantadas.

"A minha morte, a minha irremediável morte tinha acabado ali". (2009, p.14-15)

Tomando-se por verdade seu desabafo, a avó Faninha configura, de certa maneira, uma espécie de vampiro, já que "seus olhos enormes ganhavam uma liquidez que habitualmente não tinham, como se abrissem cortinas para um outro mundo" (2009, p.15), e ela "vivia então outra pessoa, fechava-se num quarto que [...] era interdito, com uma marca de nome ou número arrancado da porta" (2009, p.15), e os que cumprem a função de narrador, "à espera de adivinhar o que o silêncio [...] dizia" (2009, p.15), passam "rapidamente por casa do ti Camotim, no no 7 da Travessa da Missão, e [...] [avisam]: 'a avó Faninha virou borboleta'” (2009, p.15).

O narrador descreve ti Camotim como sendo "Diferente da avó Faninha, [porque] para ele a morte era um caminho 
de ir e voltar, um poço fundo da antiga caverna, cuja ciência conhecia e desvendava" (2009, p.15). Ele "Tinha várias almas num só corpo e assim podia descobrir, a cada passo, uma noção de infinito que Ihe garantia a vida em várias épocas" (2009, p.15-16). Caracterizado a partir de elementos buscados em referências metafísicas e paranaturais, ti Camotim se reveste de traços que o aproximam da figura vampiresca, embora distinguido, pela voz narrativa, da avó Faninha, que "acreditava que ele tinha poderes para endireitar problemas do corpo e da alma" (2009, p.16). Entretanto, tanto ele quanto ela representam faces do tipo Monstro (cf. Furtado, 1987), diversidades ajustadas do vampiro à cultura telúrica angolana. Em posição diferente da deles dois, representando um contraponto focal na narrativa, têm-se "As outras pessoas, menos lúcidas [...], [que] fugiam dele e da sua sombra, crentes que o homem e sua sombra eram capazes de sugar toda a energia do mundo e das pessoas" (2009, p.16).

Avisado do transe introspectivo da avó Faninha, ti Camotim parte em seu socorro. Leva, "Nas mãos, a panela do fogo, mais antiga do que ele, nas duas pontas do pau que equilibrava nos ombros e, rigorosamente amarrados com vários nós, segredos que nunca [...] [se pode] decifrar" (2009, 
p.16). Como destaca o narrador, "Nessas horas, o ti Camotim não tinha sombra" (2009, p.16). Ninguém o consegue impedir de entrar no quarto em que a outra estava cerrada, e, já lá dentro, sozinho com ela, "Convocava, na sua voz de muitas línguas, os habitantes do abismo. Uma luz de fogo e fumo enchia o quarto, mas não passava nunca para fora da porta" (2009, p.16). Escuta-se, de fora, "o nome da Dona Filomena [...] crescer no meio das palavras e da fúria do fogo" (2009, p.16). Concluído o ritual, faz silêncio, e ti Camotim sai, "uma sombra imensa parecia sustentá-lo" (2009, p.16). Ele segue "trôpego para o no 7 da Travessa da Missão, o pau vazio sobre os ombros, as mãos queimadas à volta da panela do fogo" (2009, p.16). A avó Faninha retoma seu aspecto de antes, a cena se recompõe ao antigamente, "As rugas e o riso tinham[-Ihe] voltado" (2009, p.17).

Diante disso, o narrador revela:

Sabíamos então que ela tinha feito, de novo, o caminho da luz. De novo, tinha deixado algures o seu corpo e voltado bola de luz. Na morte dela não estava escrita a palavra fim nem princípio. [...] Ela era uma espécie de ser do fogo, que vivia entre mundos e entre espaços, onde um tu e um eu não eram distintos. (2009, p.17)

Ora, assim sendo, a avó Faninha, semelhantemente 
ao vampiro, era um ser entre mundos, espaços e tempos, espécie de "cadáver adiado", como Furtado chamou ao vampiro, habitando este mundo que não deveria mais ser o seu, mas no qual, indistintamente, permanece.

O narrador diz que, naquele tempo, eles - os sujeitos da enunciação narrativa - não pensavam nessas coisas de morte, de outro lado da vida, que estavam num "jardim encantado" e não sabiam (2009, p.17). Aos poucos, conforme foram crescendo, sua "pele ia ficando pelos espinhos da rosa selvagem" (2009, p.17), sua "fome era concreta, viva, brutal: água como água, carne como carne" (2009, p.17), e, sem se darem conta, "entre o dia e a noite cresciam [...] e afiavam [...] os dentes para a vida" (2009, p.17). Já, então, estavam "presos no jardim encantado do mal" (2009, p.17), mas ainda não sabiam. Um a um, a começar pelo mais velho deles, desaparecia no no 7 da Travessa da Missão, enquanto a mulemba do quintal crescia mais um anel. Como revela o narrador, perderam "os centros fixos, as verdades absolutas" (2009, p.17).

Enigmaticamente, sem explicações que reponham, sob uma perspectiva racional e aristotélica, a lógica em seu lugar e, sequer, sem questionamentos que ponham os acontecimentos narrados em dúvida, a narrativa tem seu 
fecho, interligando o no 7 ao no 77: “A avó Faninha e o ti Camotim continuaram a trocar sombras, entre o número 7 da Travessa da Missão e o inexistente número 77 da rua do mesmo nome" (2009, p.17). Fica, contudo, a questão a ser desvendada: o que existia, existiu ou existe no percurso entre o 7 e a sua duplicação - 77? Sem achar a resposta, em minha condição de leitor, hesito e, incerto diante de tantas ambiguidades, não encontro como adivinhar a decifração desse caso, cujas dúvidas permanecem para além do desfecho da história - exatamente como Todorov ou Furtado afirmaram ser próprio da narrativa fantástica.

IV. A narrativa de José Eduardo Agualusa, "M., de malária" (2009, p.87-96), tem início no Brasil, mais precisamente no Rio de Janeiro, migrando para Luanda, em Angola, onde se dão as ações nucleares do cerne fantástico, e termina com um diálogo que tensiona passado-presentefuturo, entre África e Brasil, consagrado pela dúvida final, experienciada pelo destinatário intratextual e transmitida ao leitor - exatamente como, tanto Furtado, quanto Todorov propuseram que se dê no gênero.

O início da história não prenuncia qualquer evento insólito, pois não antecipa alusões a qualquer coisa - objeto, ser ou ação - que aponte para o território do fantástico. A narrativa 
se inicia in media res, com o narrador caracterizando-se, como personagem - trata-se de um narrador autodiegético - ao afirmar: "Sou um bom médico, embora nunca tenha frequentado nenhuma faculdade de medicina" (AGUALUSA, 2009, p.87), ao que completa, com uma explicação que elimina possíveis dúvidas ou ambiguidades quanto à sua condição no momento: "Comprei o diploma uma semana depois de desembarcar em Luanda" (2009, p.87). Em continuidade, ele ainda circunstancia sua atual colocação profissional "numa clínica privada" (2009, p.87) e sua formação na "Universidade Pombo Neto, de Roraima" (2009, p.87), finalizando esse introito ao confidenciar: "Não me parece provável que apareça neste princípio de mundo alguém proveniente de um lugar como Roraima, muito menos médico, capaz de denunciar-me" (2009, p.87). Inevitavelmente, o leitor está diante de uma história de fraude, falsidade, malogro, que não remete para a ambiência do fantástico.

Em flashback, o narrador retorna à gênese dos acontecimentos. Fala de sua atividade profissional antes de se fazer passar por médico: "Fui taxista durante sete anos no Rio de Janeiro" (2009, p.87). Delimita cronotopicamente a ação que desencadeou o que vai relatar a seguir: "Numa tarde de Março (era domingo e chovia) parei para receber um cliente, 
um crioulo obeso, abraçado a pasta de couro. Foi no Leblon, cruzamento da Ataulfo de Paiva com a General Artigas" (2009, p.87). Narra o fato primeiro e motivador da história:

O homem abriu a porta, atirou a pasta para o banco e preparava-se para se abater com um suspiro gordo e molhado sobre os estofos de couro. Eu já o via sentado lá atrás, a voz cansada, pedindome que o levasse para algum lugar onde brilhasse o Sol, quando, antes que tudo isso acontecesse, alguém o puxou pela camiseta e lhe meteu uma bala na cabeça. Escutei o estampido, vi o sangue iluminar o asfalto e carreguei a fundo no acelerador. Uma segunda bala estilhaçou o espelho retrovisor do lado direito. Corri disparado pela Ataulfo de Paiva e só parei depois de passar o Jardim de Alah.

Chovia violentamente Bátegas sólidas, pesadas como berlindes, quebravam-se com fragor de encontro às vidraças. Não havia viva alma nas ruas. Saí, contornei o carro. A água limpara o sangue que pudesse ter respingado sobre o metal. Abri a porta, espreitei e vi a pasta de couro. Abria-a. Voltei a fechá-la, atordoado. (2009, p.87-88)

As revelações do narrador levam qualquer leitor a crer que se trate de uma narrativa de mistério policial, uma vez que não esclarece o que havia na pasta, nem complementa com mais informações sobre o sujeito da pasta, que o leitor supõe ter morrido. 
Imprimindo novo corte na sequenciação e voltando ao espaço em que se encontrava no início da história - estratégia comum na linguagem cinematográfica -, o narrador sintetiza: "Na manhã seguinte comprei bilhete para Angola" (2009, p.88), Com isso, já sabendo que o narrador comprara diploma de medicina em Angola, o leitor é levado a crer que o conteúdo da pasta fosse demasiado valioso, e que a personagem houvera fugido para o anonimato em local bastante distante a fim de dele se aproveitar, livrandose, inclusive, das complicações correlacionadas ao crime.

O que o levou a Angola, lugar de que "Nunca ouvira falar [...] até encontrar no Aeroporto do Galeão um publicitário baiano recém-chegado de Luanda" (2009, p.88), que a descreve sendo um espaço alucinante, "como a Bahia" (2009, p.88), "confusão multiplicada por cinco" (2009, p.88), "todo o mundo a cheirar cocaína" (2009, p.88), "um lugar onde tudo está por estrear" (2009, p.88), foi a expectativa de poder, lá longe, do outro lado do Atlântico, desfrutar impunemente do que achou no interior da pasta: "Dentro da pasta do defunto havia trezentos mil dólares em notas grandes, mais uma agenda cheia de nomes" (2009, p.89). Assim, revela: "Num dia eu era um pobre taxista chamado Miro Bandarra e no outro um médico bem instalado na vida: Almir Kegler II" (2009, p.89). 
Em meio à sua vida quotidiana,

uma casa num condomínio de luxo [...], outra nas cálidas praias do Mussulo, [...] pequeno apartamento, na Maianga [...], motorista [...], um Mercedes prateado [...] [e] uma jovem advogada portuguesa, que vem a Luanda de dois em dois meses, [...] deixando em Lisboa o marido e um filho pequeno $(2009, \mathrm{p} .89)$

A personagem se vê ameaçada pelo encontro inesperado com alguém que parece conhecê-la de seu passado no Brasil. Disfarça, desconversa, e a vida segue.

Após essas informações e peripécias do narrador, uma marcação impressa entre os parágrafos - “***” - demarca, fisicamente, no papel, uma mudança abrupta no feixe efabulativo. De salto, a narrativa abandona, sem aviso prévio no plano verbal, a seara do mistério policialesco e adentra o universo do fantástico. Senta-se, diante de si, em seu consultório, "Michael M. - 55 anos, natural de Berlim, Alemanha, empresário" (2009, p.89). O narrador descreve-o com requintes e esmero oitocentistas de detalhes. Ele queixava-se de fortes dores no corpo e de frios e calafrios. Contou que "Sofrera febre alta durante as últimas noites e nem assim lhe passara o frio" (2009, p.90). Revelou: "Sonhei que me afundava num poço de águas escuras [...]. Quando acordei a minha cama parecia uma banheira, os lençóis pesados, tipo lama" (2009, p.90). 
O falso médico "chama uma enfermeira para que [...] extraísse um pouco de sangue e mandasse fazer uma 'gota espessa'" (2009, p.90). Enquanto o exame é feito, o extaxista discorre longamente sobre a malária. Nesse ponto, a narrativa incursiona por referências a fatos da história social de África, o colonialismo e aspectos circundantes. Michael, que tudo escutou em silêncio, pergunta: "Malária?! Você acha realmente que tenho malária?" (2009, p.90), completando com a chave do insólito por vir: "Isso é um completo absurdo!" (2009, p.90). Surpreso diante da assertiva, o figurante de médico pergunta-lhe: "Por que absurdo?" (2009, p.90). E a resposta que se lhe dá instaura, no seio da narrativa, a incongruência insólita que leva ao centro do fantástico: "Porque não pode ser, doutor. Eu sou um vampiro, compreende?" (2009, p.91).

Entre desconcerto mútuo, os dois riem, até acalmaremse. "Michael recostou-se na cadeira e insistiu: 'Sou um vampiro prânico"” (2009, p.90). Recorrendo à "teosofia do filósofo sueco Emanuel Swedenborg" (2009, p.91) - o recurso a figuras de autoridade, sejam buscadas nos mundos referenciais de base, sejam compostas ficcionalmente no mundo possível narrativo, é uma estratégia muito utilizada no discurso fantástico -, Michael explica: 
Os vampiros prânicos alimentam-se de energia dos outros. Infiltram-se em casamentos e aniversários, em concertos de música popular, nas turbas radiantes que enchem as praias ou as avenidas. Servem-lhe melhor ainda as cidades nervosas, [...] em cujas ruas se concentram multidões desvairadas, às gargalhadas, aos gritos, aos insultos, aprisionadas em meio ao trânsito e ao calor. Um vampiro prânico aprende a controlar e servir-se positivamente da própria energia, podendo utilizá-la em benefício de terceiro. (2009, p.91)

Verdade ou não, o pretenso médico diz que compreende, Michael seria "então uma espécie de anjo caído..." (2009, p.91), ao que este retruca, esclarecendo que "Um rebelde, digamos antes" (2009, p.91), e aquele contrapõe, em forma de pergunta, “Como Lúcifer?" (2009, p.91), para que o outro remate, advertindo: "Não pronuncie em vão o iluminado nome Dele!" (2009, p.91). E o embate é interrompido pelo retorno da enfermeira com o resultado do exame, que dera positivo. Como comenta o narrador, "Michael não protestou" (2009, p.91).

Ainda há o registro de mais uma conversa entre os dois, durante o repouso do doente. Falam de amor transitório para os mortais e de amor eterno para os vampiros. O narrador confessa nada saber de vampiros, sobre os quais não tem 
nenhum interesse. Novamente, um acontecimento externo à conversa lhe põe fim, pois "um rapazinho contorcia-se no chão" (2009, p.92) e o fingido médico foi "em socorro do menino" (2009, p.92), esquecendo-se de Michael.

Novamente, a mesma marca impressa no papel - "***” -, entre parágrafos, delimita uma passagem no feixe efabulativo. "Michael morreu durante a noite. Malária cerebral" (2009, p.92).

Durante o enterro, o narrador avistou várias personalidades - algumas dessas, personagens da história: "o publicitário baiano, na fila da frente, amparando uma mulher alta e gloriosa" (2009, p.92) - que é descrita, também, com requintes e esmeros de detalhes -, "Um banqueiro português. Um geólogo romeno. Um próspero homem de negócios de Nova lorque." (2009, p.92). Por fim, diz ele: "Sandro veio ter comigo à saída do cemitério" (2009, p.93).

O encontro desses dois, que desemboca em um jantar no "Cais de Quatro [...] um dos restaurantes mais populares de Luanda" (2009, p.93), no sábado próximo, encaminha a narrativa para seu desfecho e instala, exemplarmente, a hesitação (Todorov), a incerteza (Bessière), a ambiguidade (Furtado) quanto ao ocorrido - esse recurso utilizado por Agualusa lembra a mesma estratégia empregada por Guy de Maupassant em “O 
Horla (primeira versão)", narrativa que se considera exemplo paradigmático de um texto fantástico bem executado.

$\mathrm{Na}$ chegada ao encontro, Sandro revela saber que o Doutor Almir "acompanhou Michael em seus últimos momentos" (2009, p.93), que teria ficado "destroçado com a morte dele" (2009, p.93), e pede que ele não se culpabilize, porque "Michael morreu devido à sua própria irresponsabilidade" (2009, p.93). Essa última informação dada por Sandro faz com que o falso médico lhe pergunte: "O que você quer dizer? Que ele não tomava precauções? Que procurou ajuda demasiado tarde?" (2009, p.93). Isso desencadeia o diálogo extenso, no qual se encontram os elementos discursivos que promoverão a dúvida.

A conversa entre os dois, regada a vinho, vagueia por assuntos periféricos. Sandro se refere a um poeta de Luanda, que já teria morrido, David Mestre, e recita alguns versos de sua autoria, que falariam, segundo a percepção do médico farsante, do "hálito imortal do amor" (2009, p.94). É nesse entrecho que Sandro diz supor que Michael Ihe tenha falado deles, recebendo por resposta um abano incrédulo de cabeça, com a avaliação de que "Michael estava muito doente. Tinha febre. As pessoas deliram com febre, caminham como funâmbulos no fino fio da fronteira entre o sonho e a realidade" (2009, p.94). 
Sandro considera que "Michael já caminhava nesse fio da fronteira [...] desde há muito tempo. Como um funâmbulo, sim, mas sem rede" (2009, p.94). E avalia que "Foi ingenuidade dele pensar que era possível afastar-se. [Porque] Não somos um clube" (2009, p.94). Imediatamente, seu interlocutor replica: "Não sei de que está falando" (2009, p.94). Mas Sandro Ihe contesta, afirmando que "Sabe, sabe até bem de mais" (2009, p.95). Ele revela que lembra "do outro, o taxista" (2009, p.95), conhece a história, e pede para que "Não se preocupe" (2009, p.95), porque pode esquecerse de tudo, como o outro esquecera.

Todavia, Sandro revela "que aquele homem baleado, aquele sujeito que tentou entrar no táxi de Miro Bandarra [...] não morreu. Está preso. [...] numa penitenciária de segurança máxima [...] mas continua controlando uma das facções do Comando Negro" (2009, p.95). Por isso, diz que "se estivesse na pele de Miro Bandarra nunca mais poria os pés no Brasil" (2009, p.95). Assustado, este exclama: "Santo Deus!" (2009, p.95), e aquele, rindo "um riso leve, delicado" (2009, p.95), avisa-lhe que "Deus não o pode ajudar [...]. Quem o pode ajudar está perto de si. Não pense em nós como um clube, insisto, esse foi o erro do Michael: somos uma condição" (2009, p.95). 
Confuso, Miro/Almir pergunta-lhe "Como assim?" (2009, p.95). E Sandro responde-Ihe, alertando-o para que "Não estamos de passagem. Passeamos, o que a mim me parece diferente. Observamos. Temos muita gente aqui em Luanda. É uma cidade incrível, um vasto corpo a arder em febre" (2009, p.95). Encurralado, amedrontado, procurando decifrar o caso, o ex-taxista, agora falso médico, inquire: “O que você está me propondo?" (2009, p.95). Sandro resume: “Para já, amizade. Nesta cidade ninguém sobrevive sem uma boa rede de amigos. E um dia, quem sabe?, talvez você possa aceder à nossa condição. Você demonstra certas qualidades. O que me diz?" (2009, p.95).

Salvo engano de leitura ou submissão apriorística e desavisada à estética - ou poética, depende de onde e para onde parte o olhar - fantástica, o enigma, o mistério, a dúvida, a incerteza atinge seu clímax nessa passagem da narrativa. Michael seria, de fato, um vampiro? Sandro, também, como Michael, seria vampiro? Haveria uma sociedade desses sujeitos em "condição" vampiresca? A "boa rede de amigos" de que Sandro fala seria a sociedade dos vampiros? Estaria Sandro convidando o outro a aderir à rede? Michael teria falhado com a sociedade? Se sim, qual falha tivera? Na condição de leitor, estou, eu também, contaminado pela sensação emanada pelo personagem- 
narrador autodiegético e me sinto encurralado diante de tantas incertezas, sentindo-me impossibilitado de adivinhar uma possível decifração para o enigma textual.

O narrador, como eu -nesse momento da narrativa, da leitura, igualamo-nos como par homólogo de um mesmo sujeito hesitante, em dúvida -, não se sente capaz de responder: "Não respondi. Sou hipocondríaco. O problema, conosco, hipocondríacos, é que nos basta a sugestão de um novo mal para que logo nos interessemos por ele. Em poucos dias começamos a experimentar os sintomas. Adoecer é a forma que temos de nos curar" (2009, p.96). Sua revelação é, no entanto, inusitada e, no plano discursivo, inesperada, já que, em momento algum do relato, houve qualquer alusão à sua condição de hipocondríaco. Logo, soa como fuga a uma resposta impossível de dar e configura nova estratégia textual que corrobora com poética - ou estética, como já disse alhures - do fantástico.

A narrativa tem fecho com um parágrafo extremamente curto, em que o narrador declara: "Passaram-se meses. Nunca me senti tão bem" (2009, p.96). No entanto, a leitura não se fecha, pois eu, leitor, fico sem saber tantas coisas sobre o homem baleado, sobre Michael, sobre Sandro e, por fim, sobre o próprio narrador. O que houve? Não o sei dizer. 
V. A despeito de a presente leitura, muito desenvolvida com base na paráfrase dos textos ficcionais e muito pouco remissiva aos suportes teóricos que lhe emprestam sustentação, ter ficado ainda devendo, exatamente por suas limitações espaciais, uma maior e mais verticalizada abordagem dos dois contos, é, contudo, inegável - e não é favor que se não lhe negue - que ela destaca e realça, nas duas narrativas, aspectos de composição - suas armações de mundos possíveis ficcionais - insólita. Ambas encontramse perfeitamente integradas no exemplar que se pretende como um conjunto de contos de vampiros no universo da literatura fantástica.

Ana Paula emprega alguns recursos mais esparsos do gênero ou modo, sem, no entanto, fugir do cerne do discurso fantástico, encerrando com as incertezas quanto às figuras da avó Faninha e de ti Comotim e sobre a existência ou não do no 77 da Rua da Missão. Agualusa explora mais elementos compositivos da narrativa fantástica, transporta, do nível do enunciado para o da enunciação, a própria condição inusitada e surpreendente dessa categoria discursiva e, como Ana Paula, finaliza o texto sem dar fechamento às questões postas em dúvida ao longo da narrativa. Tratamse, efetivamente, de dois exemplares bem-acabados de narrativa fantástica, na veia da temática vampiresca. 
Veja-se lá que esse labor intelectivo e artístico, inscrito sob vários ângulos semiológicos na seara do fantástico literário, é produto de dois escritores angolanos: Ana Paula Tavares e José Eduardo Agualusa. Seria esse, sob meu olhar não africano, sequer angolano, branco e eurocêntrico que assumidamente sou, mais um aspecto a considerar insólito? Não o sei dizer. Fica, portanto, mais uma incerteza por resolver.

\section{REFERÊNCIAS}

AGUALUSA, José Eduardo. “M., de malária”. In: SENA-LINO, Pedro (coord.). Contos de vampiros. Porto: Porto, 2009. p.87-96.

BESSIÈRE, Irène. Le recit fantastique. La poetique de l'incertain. Paris: Larousse Université, 1974.

. "El relato fantástico: forma mixta de caso y adivinanza". In: ROAS, David (intr., comp. y bibl.). Teorías de lo fantástico. Madrid: Arco/ Libros, 2001. p.83-104.

FURTADO, Filipe. A construção do fantástico na narrativa. Lisboa: Horizonte, 1980.

- Demónios íntimos. A narrativa fantástica vitoriana (origens, temas, ideias). Dissertação de Doutoramento. Lisboa: Faculdade de Ciências Sociais e Humanas da Universidade Nova de Lisboa, 1987.

SENA-LINO, Pedro. "Nota introdutória". In: Contos de vampiros. Porto: Porto, 2009. p.9-10.

PEPETELA. Lueji: O Nascimento de um Império. 3ed. Lisboa: Dom Quixote, 1997.

TAVARES, Ana Paula. "O mistério da Rua da Missão". In: SENA-LINO, Pedro (coord.). Contos de vampiros. Porto: Porto, 2009. p.13-17.

TODOROV, Tzvetan. Introdução à literatura fantástica. 2ed. São Paulo: Perspectiva, 1992. 
Flávio Garcia concluiu, em março de 2016, seu terceiro Pós-Doutorado, com Bolsa de Estagio Sênior da CAPES, na Faculdade de Letras da Universidade de Coimbra (FLUC), intitulado "Estudos Narrativos do Insólito Ficcional: mundos possíveis", sob a supervisão do Prof. Doutor Carlos Reis; em junho de 2012, seu segundo Pós-Doutorado, no PPG em Letras da UFRGS, na área de Estudos da Literatura, intitulado "O insólito ficcional nas narrativas curtas e de média extensão de Mia Couto: o recurso a estratégias de construção narrativa realista-maravilhosas como vertente possível da literatura contra-hegemônica moçambicana", sob a supervisão da Profa. Dra. Jane Tutikian; em fevereiro de 2008, seu primeiro Pós-Doutorado, no PPG em Ciência da Literatura da UFRJ, na área de Poética, intitulado "Questões de gênero literário em narrativas curtas da literatura da lusofonia", sob a supervisão do Prof. Dr. Manuel de Castro; defendeu, em 1999, o Doutorado em Letras na PUC-Rio, tendo apresentado a Tese intitulada "O Realismo Maravilhoso na Ibéria Atlântica: a narrativa curta de Mário de Carvalho e Méndez Ferrín", sob a orientação do Prof. Dr. Nelson Rodrigues Filho; em 1995, o Mestrado em Letras na UFF, tendo apresentado a Dissertação intitulada "Gil Vicente e as Dissertações de Mestrado no Rio de Janeiro: um painel", sob a orientação da Profa. Dra. Maria do Amparo Tavares Maleval. É Professor Associado da UERJ, atuando na Graduação em Letras e no PPG em Letras, na área de Estudos de Literatura, nas especificidades de Literatura Portuguesa e de Teoria da Literatura e Literatura Comparada, com orientações de Mestrados e Doutorado. 